\title{
Diet composition and feeding strategy of the southern pipefish Syngnathus folletti in a Widgeon grass bed of the Patos Lagoon Estuary, RS, Brazil
}

\author{
Alexandre M. Garcia*, Ricardo M. Geraldi**, \\ and João P. Vieira**
}

Pipefish species are poorly known representatives of the family Syngnathidae, which have been increasingly threatened by anthropogenic activities. We describe the diet composition and feeding strategy of southern pipefish Syngnathus folletti inhabiting a Widgeon grass (Ruppia maritima L.) bed in the estuarine zone of Patos Lagoon, southern Brazil. We also investigated whether mouth gape affected the size of prey items consumed and based on indirect evidence, we suggest possible pipefish foraging movements within the bed. Individuals were collected from December 1994 to March 1995 in a Ruppia maritima bed located in the Patos Lagoon Estuary during day and night periods. We analyzed the stomach contents of 108 individuals ( 54 females and 54 males). Both genders seemed to be diurnal carnivores with diets composed primarily of copepods and isopods. Mixed feeding strategies were evident with varying degrees of specialization on different prey types. Females had a more diverse diet both in prey richness as in prey size range, whereas males fed primarily on smaller prey, the isopod U. peterseni and copepods. Gender-based diet differences suggest that females may be more mobile and active inside the Widgeon grass bed than males. The average size range of the two dominant prey items fitted well to the pipefish mouth gape $(0.4$ to $1.4 \mathrm{~mm})$. However, a few female individuals were able to consume prey three times larger than their maximum gape. A diagram of prey microhabitat suggested that both genders browse and capture invertebrates over the entire vegetated substrate provided by the Widgeon grass bed.

Peixes-cachimbo são espécies pouco conhecidas da família Syngnathidae, os quais têm sido amplamente ameaçados por atividades antrópicas. Este trabalho descreve a composição da dieta e estratégia alimentar de uma população do peixecachimbo Syngnathus folletti habitando uma pradaria de fanerógama submersa no estuário da Lagoa dos Patos, RS, Brasil. Também é investigado como a amplitude bucal afeta o tamanho das presas consumidas e, baseado em evidências indiretas, são sugeridos padrões de deslocamento da espécie no interior da pradaria. Entre Dezembro de 1994 e Março de 1995, os indivíduos foram coletados de dia e de noite numa pradaria de Ruppia maritima L. localizada no estuário da Lagoa dos Patos. Os conteúdos estomacais de 108 indivíduos (54 machos e 54 fêmeas) foram analisados. Ambos os sexos parecem ser carnívoros diurnos com uma dieta composta principalmente de copépodes e isópodes. Os resultados sugerem uma estratégia alimentar do tipo mista com vários graus de especialização para determinadas presas. As fêmeas tiveram uma dieta mais diversa, consumindo maior variedade de presas, as quais mostraram maior variabilidade em tamanho, enquanto os machos parecem ter se concentrado em presas menores, como o isópode Uromunna peterseni e copépodes. Essas diferenças entre sexos sugerem que as fêmeas são mais móveis e ativas dentro da pradaria do que os machos. Houve uma boa concordância entre o tamanho médio das presas dominantes e a amplitude bucal $(0,4$ e $1,4 \mathrm{~mm})$, contudo, algumas fêmeas foram capazes de consumir presas três vezes maiores do que sua máxima amplitude bucal. Um diagrama mostrando a utilização de micro-hábitats pelas presas sugere que machos e fêmeas do peixe-cachimbo capturam presas sob todo o substrato vegetal disponível no interior da pradaria de $R$. maritima.

Key words: Syngnathidae, Ruppia maritima, feeding ecology, size-biased feeding, prey size.

\footnotetext{
*Universidade Federal do Rio Grande do Sul, Instituto de Pesquisas Hidráulicas, CP 15029, Porto Alegre, RS, Brazil. e-mail: amgarcia@mikrus.com.br - send reprint requests to AMG.

**Fundação Universidade Federal de Rio Grande, Depto de Oceanografia, Laboratório de Ictiologia, CP 474, Rio Grande, RS, Brasil. e-mail: (RMG) ricardomgeraldi@yahoo.com, (JPV) vieira@mikrus.com.br
} 


\section{Introduction}

Pipefish and seahorses attract economic interest because of their value as aquarium fish, ingredients in traditional Chinese medicine, supplements in specialized cuisine, and as curiosities (Payne et al., 1998). This anthropogenic pressure has resulted in serious threats to Syngnathid fishes inhabiting coastal Brazilian waters, and recently resulted in the inclusion of Brazilian seahorses in the IUCN red List of Threatened Animals (Rosa et al., 2002; Dias et al., 2002). Therefore, it is critically important to improve the biological and ecological knowledge of Syngnathid species inhabiting Brazilian waters, especially for populations occurring in estuarine systems with high human-densities.

Pipefish species are common in seagrass beds, where their elongate body effectively mimic stems or bunches of seagrass (Howard \& Koehn, 1985). They also have an elongate tubular snout and small terminal mouth (Bergert \& Wainwright, 1997) indicating that they may be gape-limited relative to larger prey items (Ryer \& Orth, 1987). Syngnathids are sexually dimorphic, and males nurse their offspring on the body surface or in a brood pouch. In terms of reproductive investment, females contribute eggs, whereas males fertilize them inside the brood pouch and provide nutrition and oxygen to the offspring (Teixeira \& Vieira, 1995). This reproductive system can result in substantial reproductive costs to males including lower food intake, slower growth, increased preda-
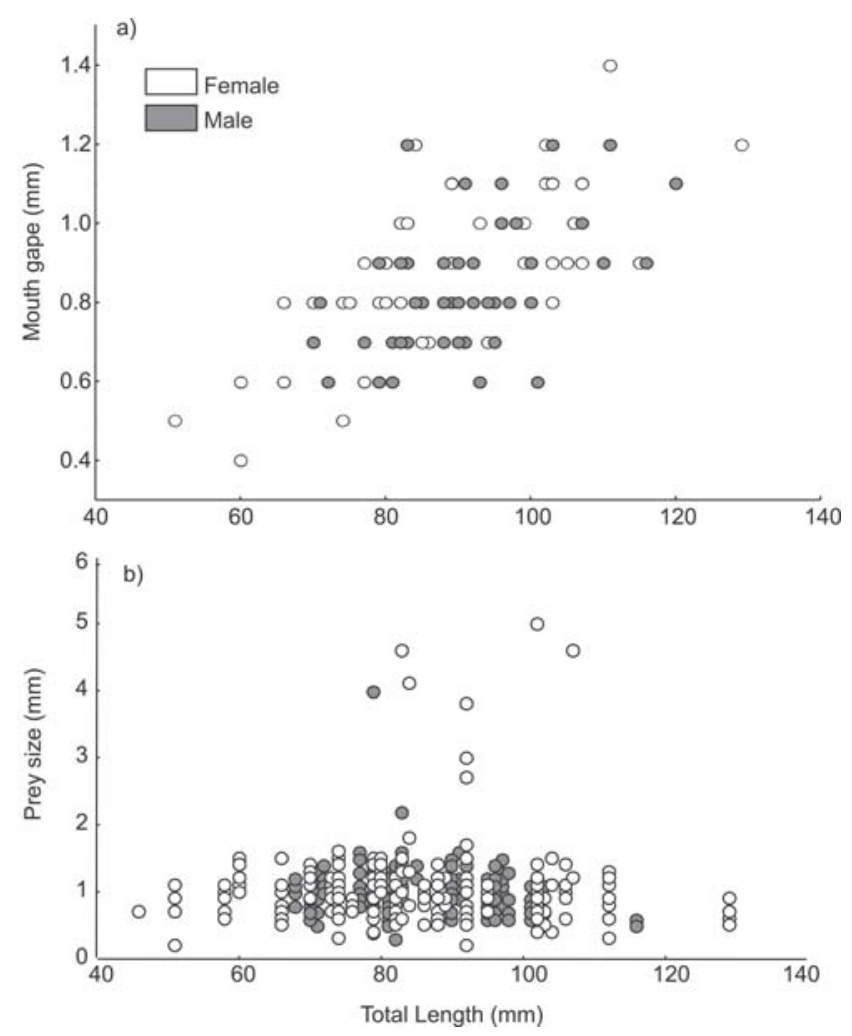

Fig. 1. Relationship between mouth gape (a) and prey size (b) with total length (in mm) of female (open circles) and male (dots) individuals of the southern pipefish Syngnathus folletti. tion risk, and lower winter survival compared to females (Svensson, 1988; Steffe et al., 1989). Such differential reproductive costs may be reflected in differential prey selection by males and females (Svensson, 1988).

The southern pipefish (Syngnathus folletti) occurs from northern Brazil (near Fortaleza, CE) to Uruguay and Argentina (Dawson, 1982). Other than the taxonomic description, published information about the southern pipefish is restricted to a few studies on the population inhabiting the estuarine zone of Patos Lagoon. Chao et al. (1985) suggested this species is a resident fish in the estuary. Teixeira \& Vieira (1995) investigated its reproductive biology, and Garcia \& Vieira (1997) showed that Widgeon grass bed Ruppia maritima L. seem to be a preferred habitat, where the species feeds and reproduces. With exception of a few remarks regarding diet composition in Teixeira \& Vieira (1995), there is no detailed study on the feeding habits of the southern pipefish.

In this paper, we describe the feeding habits of the southern pipefish and compare dial feeding patterns and diet composition between males and females. We also discuss whether restricted mouth gape, which is a common feature of pipefish species, may affect the total length of consumed prey. Finally, based on a conceptual diagram showing prey microhabitat utilization, we suggest potential pipefish foraging movements within the Widgeon grass bed.

\section{Material and Methods}

Field sampling and laboratory work. Individuals were collected fortnightly, during day and night periods, from a Widgeon grass bed (Ruppia maritima L.) located in the estuarine zone of Patos Lagoon (near Pombas Island, Arraial Embayment). Sampling took place from December 1994 to March 1995, which corresponded to the onset and disappearance of the Widgeon grass bed. A total of 265 individuals were collected and 108 individuals (54 females and 54 males) were selected for stomach contents analysis, with total lengths (mm) ranging from 46 to 129 and 70 to 120 , and total weights (g) ranging from 0.02 to 0.65 and 0.09 to 0.69 for females and males, respectively. Further details concerning the sampling protocol and patterns of abundance and occurrence of all fishes collected inside and outside of the Widgeon grass bed can be found in Garcia \& Vieira (1997).

In the laboratory, individuals were identified following Dawson (1982), sexed, measured (TL mm) and weighed (g), and stomachs were dissected for analysis. Each food item in the stomach was identified to the lowest possible taxonomic level, or when necessary, assigned to different food categories such as organic matter (animal and vegetal), copepoda, isopoda, tanaidacea, gastropoda, amphipoda, ostracoda, cumacea, megalopa, fish larvae, shrimp and sand. As a proxy for the relative abundance of each prey item, we counted the number of individuals for each item and calculated the area $\left(\mathrm{mm}^{2}\right)$ occupied by each food item. Only the area was recorded 
for the "organic matter" category. In order to measure area, the food item was removed from the stomach and evenly spread along a metric paper attached to a Petri dish, and then the number of millimeter squares occupied by the item was recorded. Considering that pipefish species usually feed with suction without biting or crushing the prey, most items were found as entire individuals in the stomach. Whenever prey where whole, we measured the total length $(\mathrm{mm}$ ) of individual food items.

Data analysis. We used the graphical analysis proposed by Amundsen et al. (1996) to interpret the stomach contents data. This method is a modification of the traditional method of Costello (1990) and allows prey importance, feeding strategy, and inter- and intra-individual components of niche breadth to be analyzed by a two-dimensional representation of prey abundance and frequency of occurrence (Amundsen et al., 1996; Deus \& Petrere-Junior, 2003).

Costello (1990) and Amundsen et al. (1996) used different methods to calculate prey relative abundance (or contribution to the stomach contents). Costello defined relative abundance of prey as the percentage of total stomach contents (volume, weight or numbers) in all predators comprised by that given prey. In contrast, Amundsen proposed the

Table 1. Average number, average area (in $\mathrm{mm} 2$ ) occupied by each item and frequency of occurrence (FO\%) for each food item for female and male Syngnathus folletti during day and night.

\begin{tabular}{|c|c|c|c|c|c|c|}
\hline \multirow[b]{3}{*}{ FEMALE } & \multicolumn{3}{|c|}{ DAY } & \multicolumn{3}{|c|}{ NIGHT } \\
\hline & \multicolumn{3}{|c|}{12 item } & \multicolumn{3}{|c|}{10 item } \\
\hline & Num & Area 1 & $\mathrm{FO} \%$ & Num & Area & $\mathrm{FO} \%$ \\
\hline Uromunna peterseni (Isopoda) & 92.5 & 46.8 & 72.7 & 17.7 & 13.0 & 60.0 \\
\hline Copepoda & 105.8 & 35.4 & 72.7 & 12.0 & 5.3 & 10.0 \\
\hline Organic matter (animal) & 0.4 & 4.8 & 36.4 & 0.9 & 10.0 & 80.0 \\
\hline Heliobia australis (Gastropoda) & 10.9 & 3.6 & 9.1 & 4.0 & 2.0 & 10.0 \\
\hline Mellita mangrovi (Amphipoda) & 0.5 & 2.6 & 18.2 & 0.1 & 0.6 & 10.0 \\
\hline Fish larvae & 3.3 & 4.4 & 9.1 & & & \\
\hline Organic matter (vegetal) & & & & 0.1 & 0.6 & 10.0 \\
\hline Ostracoda & 0.3 & 0.1 & 27.3 & 0.1 & 0.0 & 10.0 \\
\hline Sand & 0.2 & 0.0 & 18.2 & 0.1 & 0.0 & 10.0 \\
\hline Shrimp (Crustacea) & & & & 0.1 & 0.0 & 10.0 \\
\hline Kalliapseudes schubartii (Tanaidacea) & 0.1 & 0.3 & 9.1 & & & \\
\hline Tanais stanfordi (Tanaidacea) & & & & 0.1 & 0.0 & 10.0 \\
\hline Cumacea & 0.1 & 0.1 & 9.1 & & & \\
\hline Dies fluminensis (Isopoda) & 0.1 & 0.0 & 9.1 & & & \\
\hline Megalopa & 0.1 & 0.0 & 9.1 & & & \\
\hline TOTAL & 214.2 & 98.1 & & 35.2 & 31.5 & \\
\hline MALE & & 7 item & & & 10 iten & \\
\hline Uromunna peterseni (Isopoda) & 147.7 & 72.2 & 85.7 & 57.3 & 40.2 & 72.8 \\
\hline Copepoda & 81.0 & 24.5 & 66.7 & 3.8 & 4.8 & 53.8 \\
\hline Organic matter (animal) & 0.7 & 10.3 & 66.7 & 0.3 & 1.4 & 30.8 \\
\hline Heliobia australis (Gastropoda) & & & & 6.7 & 4.4 & 23.1 \\
\hline Mellita mangrovi (Amphipoda) & 0.2 & 0.2 & 16.7 & 0.7 & 0.8 & 23.1 \\
\hline Fish larvae & 0.2 & 0.2 & 16.7 & 1.3 & 0.3 & 15.4 \\
\hline Organic matter (vegetable) & 0.2 & 0.2 & 16.7 & 0.1 & 0.3 & 7.7 \\
\hline Ostracoda & 0.2 & 0.1 & 16.7 & 0.1 & 0.0 & 7.7 \\
\hline Tanais stanfordi (Tanaidacea) & & & & 0.1 & 0.0 & 7.7 \\
\hline Sand & & & & 0.1 & 0.0 & 7.7 \\
\hline TOTAL & 230.0 & 107.6 & & 70.4 & 52.1 & \\
\hline
\end{tabular}

calculation of the 'prey-specific abundance of prey', which take in account only those predators in which the actual prey occurs $\left(P_{i}=\left(\mathrm{a} S / \mathrm{a} S_{t i}\right) \times 100\right.$; where $P_{i}$ is the prey-specific abundance of prey $i, S_{i}$ is the stomach content (volume, weight or number) comprised of prey $i$, and $S_{t i}$ is the total stomach content in only those predators with prey $i$ in their stomach).

According to Amundsen et al. (1996), the interpretation of the diagram (prey importance, feeding strategy and niche breadth) can be obtained by examining the distribution of points along the diagonals and axes of the graph. The diagonal from the lower left to the upper right corner provides a measure of prey importance, with dominant prey at the top, and rare or unimportant prey at the lower end. The vertical axis represents the feeding strategy of the predator in terms of specialization or generalization. Predators have specialized on prey positioned in the upper part of the graph, whereas preys positioned in the lower part have been eaten only occasionally (generalization). Prey points located at the upper left of the diagram would be indicative of specialization by individual predators, and those in the upper right would represent specialization of the predator population. Finally, in terms of niche breadth, we can envision a population with a high between-phenotype component, as different individuals specialize on different resource types, and a population with a high within-population component, as most of the individuals utilize many resource types simultaneously. Both phenotype components can be observed in the diagram. Prey with high specific abundance and low occurrence (upper left) were consumed by a few individuals displaying specialization, whereas prey with a low abundance and a high occurrence (lower right) were eaten occasionally by most individuals.

In order to indirectly infer predator foraging movements within the Widgeon grass bed, we provided a conceptual diagram showing the microhabitat utilization of some benthic macro-invertebrates consumed by Syngnathus folletti. This diagram was based on previous sampling of epifauna and infauna invertebrates conducted from December 1993 to March 1994 in a Widgeon grass bed located in the same area where the fishes were collected (Geraldi, 1997). Considering the 1-yr difference between invertebrate and fish sampling, our goal with this diagram was not to contrast diet composition with prey availability in the environment, but only to infer pipefish foraging movements (water column vs. bottom) inside the bed. Although prey availability is expected to change significantly between-years due to different abiotic conditions, prey microhabitat use seems to be more conservative because it reflects species-specific morphological and behavioral features.

Specimens examined: FURG 94.0153 (11) Ilha das Pombas, Saco do Arraial, Rio Grande, RS, Brazil, 01/12/1994; FURG 94.0154 (48), idem, 15/12/1994; FURG 95.0149 (10), idem, 01/ 01/1995; FURG 95.0150 (14), idem, 15/01/1995; FURG 95.0151 (18), idem, 01/02/1995; FURG 95.0152 (6), idem, 15/02/1995; FURG 95.0153 (1), idem, 01/03/1995. 


\section{Results}

Although the number of food items (10) found in stomachs was the same for both genders during night periods, females had a broader diet composition during the day (12 vs. 7 food items). A comparison of the abundance of prey items consumed (both in number and area occupied by the food item) during different periods (day and night) yielded higher values during the day. The dominant food items for both genders were copepods and the isopod Uromunna peterseni (Table 1).

Food items found in the stomach of both genders ranged in size from 0.52 to $4.62 \mathrm{~mm}$. The dominant items (copepods and $U$. peterseni) had an average size of 0.78 and $1.17 \mathrm{~mm}$, respectively (Table 2). The size range of these dominant prey coincides with the mouth gape (from 0.4 to $1.4 \mathrm{~mm}$ ) of both

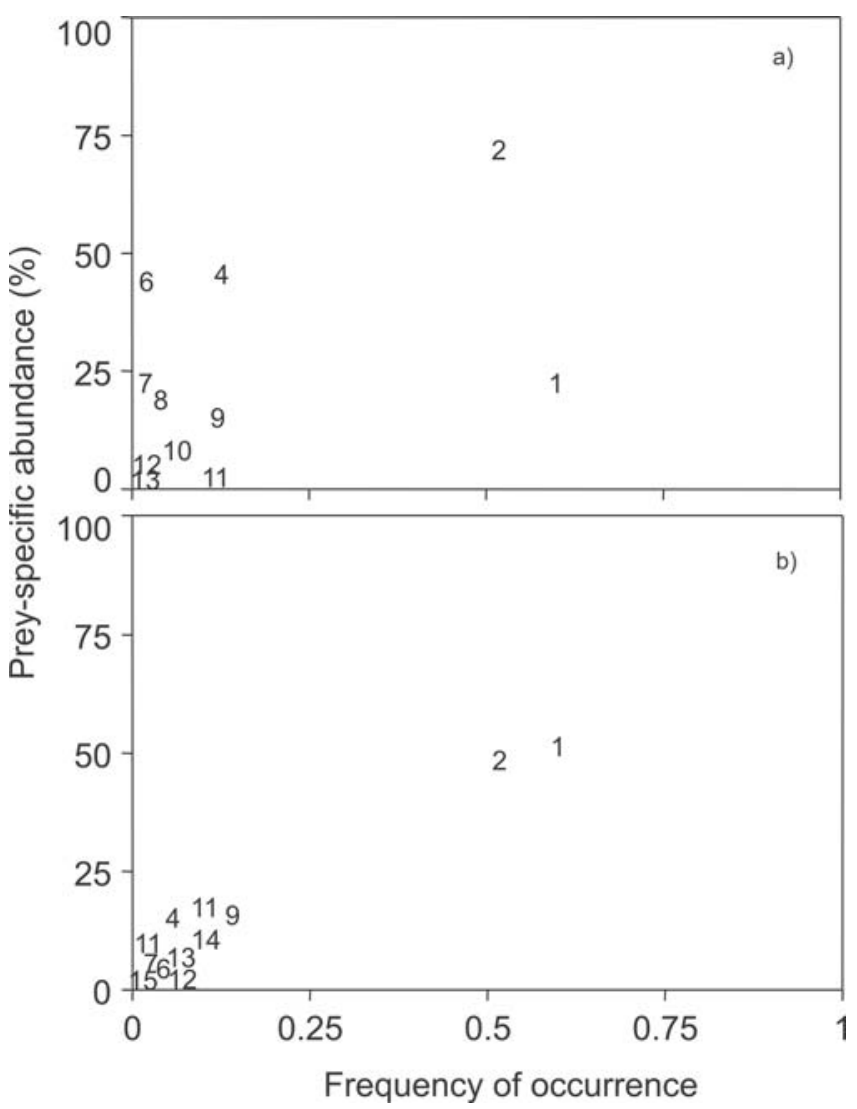

Fig. 2. Feeding strategy diagram for female (a) and male (b) individuals of Syngnathus folletti. Prey-specific abundance $(\%)$ plotted against frequency of occurrence of food items in the diet of the pipefish. Food items: 1. Uromunna peterseni (Isopoda), 2. Copepoda, 3. Organic matter (animal), 4. Mellita mangrovi (Amphipoda), 5. Organic matter (vegetable), 6. Shrimp, 7. Fish larvae, 8. Kalliapseudes schubartii (Tanaidacea), 9. Heliobia australis (Gastropoda), 10. Dies fluminensis (Isopoda), 11. Tanais, 12. Magalopa, 13. Sand, 14. Ostracoda, 15. Cumacea. Items 3 and 5 were computed in the analysis but are not plotted in the diagram. female and male pipefish (Fig. 1). In a few cases, larger prey $(>2.5 \mathrm{~mm})$ such as the tanaidacean Kalliapseudes schubartii $(4.10 \mathrm{~mm})$ and the amphipod Mellita mangrovi $(4.62 \mathrm{~mm})$ were consumed mainly by females (Fig. 1, Table 2).

Analysis of feeding strategy, based on the Amundsen's method, showed that both genders had a mixed feeding strategy, with varying degrees of specialization and generalization on different prey types (Fig. 2). When compared with males, the female population had a higher opportunism in its feeding strategy (higher between-phenotype component), showing occasional consumption of larger prey such as the amphipod (M. mangrovi), shrimp, fish larvae and Tanaidacea (K. schubartii). In terms of prey importance, copepods and isopods (U. peterseni) were the most important, with isopods being more abundant in the diet of males (Fig. 2).

According to the microhabitat conceptual diagram of selected prey, S. folletti fed upon prey usually distributed along the entire Widgeon grass bed. With the exception of one infaunal prey (K. shubartii), which was rare in the diet, consumed prey are usually found over bare substrates (Heliobia australis, Tanais stanfordi), associated with Widgeon grass's leaves (H. australis, T. stanfordi, Dies fluminensis, Mellita mangrovi) or associated with drifting macro-algae (Uromunna peterseni) (Fig. 3).

\section{Discussion}

Both genders of the southern pipefish Syngnathus folletti, occurring in the Widgeon grass beds at the Patos Lagoon Estuary, seem to be diurnal carnivores preying mainly upon copepods and isopods. They showed a mixed feeding strategy, with varying degrees of specialization and generalization on different prey types. The only previous published information (Teixeira \& Vieira, 1995), which briefly describes the diet composition of the southern pipefish, also reported copepods as the most frequent prey item (83.5\%), followed by amphipods $(6.8 \%)$, ostracods $(5.8 \%)$, mysids $(4.8 \%)$ and fish eggs (1.9\%). The authors analyzed the stomach contents of 103 individuals captured in open waters of Patos Lagoon Estuary during 1978 and 1982. The absence of isopods in the diet of these individuals contrasts with the results of the present study. The previous study did not capture pipefish in vegetated habitats and this may partially explain the con-

Table 2. Average size (total length in $\mathrm{mm}$ ), low and high $95 \%$ confident limits and number of sample (n) of selected food item found in the stomach contents of the Syngnathus folletti.

\begin{tabular}{lcccc}
\hline \multicolumn{1}{c}{ Item } & Mean (TL mm) & Low & High & $\mathrm{n}$ \\
\hline Ostracoda & 0.52 & 0.45 & 0.59 & 10 \\
Copepoda & 0.78 & 0.76 & 0.80 & 245 \\
Magalopa & 0.80 & & & 1 \\
Heliobia australis (Gastropoda) & 0.84 & 0.75 & 0.92 & 39 \\
Uromunna peterseni (Isopoda) & 1.17 & 1.14 & 1.19 & 390 \\
Dies fluminensis (Isopoda) & 1.28 & 1.17 & 1.39 & 15 \\
Fish larvae & 2.32 & 1.26 & 3.38 & 6 \\
Kalliapseudes schubartii (Tanaidacea) & 4.10 & & & \\
Mellita mangrovi (Amphipoda) & 4.62 & 4.03 & 5.21 & 6 \\
\hline
\end{tabular}


flicting results. The occurrence of isopods in the Patos Lagoon Estuary appears to be strongly associated with drifting algae (e.g., Enteromorpha sp.), that can be trapped within the Widgeon grass bed (Geraldi, 1997).

Teixeira \& Vieira (1995) suggested that the predominance of copepods in the southern pipefish's diet occurred because its small mouth gape restricted its feeding to smaller prey. Other authors (Ryer \& Orth, 1987; Franzoi et al., 1993) suggested that small mouth gape could limit suction feeding in pipefish species. Our results showed that average size of the two dominant prey items (copepoda: $0.78 \mathrm{~mm}$ and isopod $U$. peterseni: $1.17 \mathrm{~mm}$ ) were well fit to the gape width range $(0.4$ to $1.4 \mathrm{~mm}$ ) of S. folletti. However, it is interesting to note that a few individuals, particularly females, were able to consume prey three times larger than the maximum gape of their mouth, such as the tanaidacean, $K$. schubartii $(4.10 \mathrm{~mm})$ and the amphipod M. mangrovi $(4.62 \mathrm{~mm})$. During the dissection of female stomachs, we observed that just one of these larger prey filled the entire stomach volume.

The consumption of larger epifaunal prey could result in a larger energy intake than preying upon smaller zooplankton prey such as copepods. Gerking (1994) noted that a large number of fish species in many families feed by selecting the larger prey items in a population, the so-called size-biased feeding. More energy is obtained by this procedure than if the predator ate every particle encountered. Thus, theoreti-

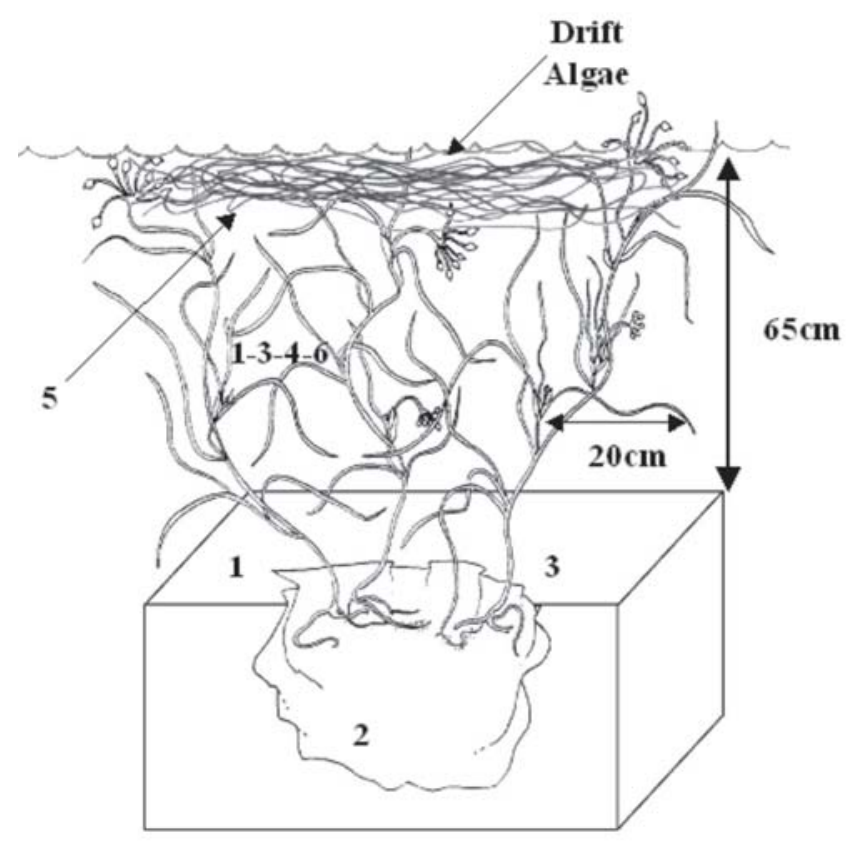

Fig. 3. Conceptual diagram showing the microhabitat distribution within the Widgeon grass bed of some benthic macroinvertebrates consumed by Syngnathus folletti. Gastropoda: 1. Heleobia australis; Tanaidacea: 2. Kalliapseudes schubartii, 3. Tanais stanfordi; Isopoda: 4. Dies fluminensis, 5. Uromunna peterseni; Amphipoda: 6. Mellita mangrovi. cally, it would be advantageous for the female pipefish to spend energy trying to capture prey larger than its mouth gape. This behavior may determine higher between-phenotype variability than previously suggested for the species by Teixeira \& Vieira (1995). Although there are few observations $(\mathrm{n}=8)$ to sustain a hypothesis, we speculate that some individuals can surpass the mouth width limitation, consuming larger prey in length than its mouth gape, by suctioning the prey from a right angle. For instance, although these prey (e.g., amphipod M. mangrovi) can measure $>4 \mathrm{~mm}$ in length, they are $<1.5 \mathrm{~mm}$ in width, and therefore can fit into the mouth gape of the southern pipefish if it is captured at the right angle. Further field and laboratory studies would be necessary to evaluate if these observed cases constitute a random pattern or an actual feeding behavior of the species.

The feeding strategy and niche breadth analyses suggested a marked between-gender variation in the diet of southern pipefish. Females had a more diverse diet both in terms of prey richness and prey size range, whereas males seemed to concentrate mainly on smaller prey, mainly the isopod $U$. peterseni and copepods. Such differences suggest females are more mobile and active within the Widgeon grass bed than males. Although pipefish species, in general, show low activity levels, some authors (Roelke \& Sogard, 1993) have demonstrated in laboratory settings that females are more active than males. These authors hypothesized that a distended brood pouch with developing young may hinder the swimming ability of males, limiting their activity levels. In fact, Svensson (1988) observed that reproductively active females had an increased activity level and a higher intake of large prey compared with reproductively active males, who were less active and fed mainly on small prey. Field and laboratory experiments would be necessary to test the hypothesis that differential activity levels related to parental care in the southern pipefish $S$. folletti could be correlated with gender differences in diet composition and feeding strategy.

Finally, in terms of predator foraging movements within the Widgeon grass bed, the microhabitat prey diagram provided indirect evidence that both male and female pipefish seem to browse and capture invertebrate prey over the entire vegetated substrate. Apparently, the heterogeneous and complex habitat formed by the Widgeon grass leaves and drifting macro-algae did not impose limitations to the foraging movements of $S$. folletti. Pipefish species in general have a well known body shape that mimics seaweed and allows them to sway slowly and easily within the vegetation (Howard \& Koehn 1985). However, as expected by its strong association with vegetation, and consequently with the water column, the southern pipefish did not consume infaunal prey that usually occur within the Widgeon bed's substrate (Geraldi, 1997), such as polychaets (Heteromastus similis, Laeonereis acuta, and Nephtys fluviatilis) and the tanaidacean Kalliapseudes schubartii. These polychaets were totally absent from the diet and $K$. schubartii occurred in relatively few stomachs. 


\section{Acknowledgments}

We thank Kirk O. Winemiller for suggestions during data analyzes, and Steve Szeug and Hernan Lopez for reviewing a first draft. The study received financial support from the Conselho Nacional de Desenvolvimento Científico e Tecnológico - CNPq (Brazil).

\section{Literature Cited}

Amundsen, P. A., H. M. Gabler \& F. J. Staldvik. 1996. A new approach to graphical analysis of feeding strategy from stomach contents data - modification of the Costello (1990) method. Journal of Fish Biology, 48: 607-614.

Bergert, B.A. \& P.C. Wainwright. 1997. Morphology and kinematics of prey capture in the syngnathid fishes Hippocampus erectus and Syngnathus floridae. Marine Biology, 127: 563-570.

Chao, L. H., L. E. Pereira, \& J. P. Vieira. 1985. Estuarine fish community of the dos Patos Lagoon, Brazil. A baseline study. Pp. 429-450. In: Yanez-Arancibia, A., (Ed.). Fish Community Ecology in Estuaries and Coastal Lagoons: Towards an Ecosystem Integration, Mexico, DR (R) UNAM Press, 653p.

Costello, M. J. 1990. Predator feeding strategy and prey importance: a new graphical analysis. Journal of Fish Biology, 36: 261-263.

Dawson, C. E. 1982. Family Syngnathidae. In: Bolke, J. E. (Ed.). Fishes of the western North Atlantic. Part eight. Order Gasteroisteiformes, Suborder Syngnathoidei. New Haven: Sears Foundantion for Marine Science, Yale University, 198 p.

Deus, C. P. \& M. Petrere-Junior. 2003. Seasonal diet shift of seven fish species in na Atlantic rainforest stream in southeastern Brazil. Brazilian Journal of Biology, 63(4): 579-588.

Dias, T. L., I. L. Rosa \& J. K. Baum. 2002. Threatened fishes of the world: Hippocampus erectus Perry, 1810 (Syngnathidae). Environmental Biology of Fishes, 65: 326.

Franzoi, P., R. Maccagnani, R. Rossi \& V.U. Ceccherelli. 1993. Life cycles and feeding habits of Syngnathus taenionotus and $S$. abaster (Pisces, Syngnathidae) in a brackish bay of the Po River Delta (Adriatic Sea). Marine Ecology Progress Series, 97: 71-81.
Garcia, A. M. \& J. P. Vieira. 1997. Abundância e diversidade da assembléia de peixes dentro e fora de uma pradaria de Ruppia maritima L., no estuário da Lagoa dos Patos (RSBrasil). Atlântica Rio Grande, 19: 161-181.

Geraldi, R. M. 1997. Estrutura da assembléia de macroinvertebrados bentônicos em fundos com e sem vegetação macrófita na região estuarial da Lagoa dos Patos, Rio Grande, RS-Brasil. Unpublished Master Thesis. Fundação Universidade Federal de Rio Grande, Rio Grande. 207p.

Gerking, S. D. 1994. Feeding ecology of fish. San Diego, Academic Press, 415p.

Howard, R. K. \& J. D. Koehn. 1985. Population dynamics and feeding ecology of pipefish (Syngnathidae) associated with eelgrass beds of Western Port, Victoria. Australian Journal of Marine and Freshwater Research, 36: 361-370.

Payne, M. F., R. J. Rippingale \& R. B. Longmore. 1998. Growth and survival of juvenile pipefish (Stigmatopora argus) fed live copepods with high and low HUFA content. Aquaculture, 167: 237-245.

Roelke, D. L. \& S. M. Sogard. 1993. Gender-based differences in habitat selection and activity level in the northern pipefish (Syngnathus fuscus). Copeia, 2: 528-532.

Rosa, I. L., T. L. Dias \& J. K. Baum. 2002. Threatened fishes of the world: Hippocampus reidi Ginsburg, 1933 (Syngnathidae). Environmental Biology of Fishes, 64: 378.

Ryer, C.H. \& R.J. Orth. 1987. Feeding ecology of the northern pipefish, Syngnathus fuscus, in a seagrass community of the lower Chesapeake Bay. Estuaries, 10: 330-336.

Steffe, A. S., M. Westoby \& J. D. Bell. 1989. Habitat selection and diet in two species of pipefish from seagrass: sex differences. Marine Ecology Progress Series, 55: 23-30.

Svensson, I. 1988. Reproductive costs in two sex-role reversed pipefish species (Syngnathidae). Journal of Animal Ecology, 57: 929-942.

Teixeira, R. L. \& J. P. Vieira. 1995. The breeding population of the pipefish, Syngnathus folletti (PISCES: SYNGNATHIDAE) from southern Brazil. Atlântica Rio Grande, 17: 123-134.
Received May, 2005

Accepted September, 2005 